\title{
FORGIVE OUR PRESUMPTION: A DIFFICULT READING OF MATTHEW 23:1-3
}

\author{
JONATHAN D. STUCKERT
}

Reformed Theological Seminary

\begin{abstract}
In Matthew 23:1-3, Jesus commands His disciples and the crowd to listen to the scribes and Pharisees even while not imitating their actions. Many modern interpreters have lessened the force of Matthew 23:1-3 by an assumption of irony on the part of Jesus. We presume that God could never ordain this for His people. However, this easier reading may not be the best reading. A more straightforward interpretation, but one that is difficult to hear, suggests that at times we may need to sit under bad leadership as means of receiving God's Word. Pre-critical and modern interpreters provide an understanding of the words of Jesus that is consistent with a theology of God's providence in times of transition and bad leadership. In addition, there are instances of His direction in both the Old and New Testaments that reinforce this challenging path. It is through this more faithful stance that we grow and flourish in difficult times.
\end{abstract}

KEY WORDS: Matthew 23:1-3, leadership, irony, seat of Moses, authority

\section{Introduction}

In Matthew 23:1-3, Jesus makes the startling statement to his disciples and the crowds that they should 'do and observe whatever' the scribes and Pharisees tell them. The reader may easily brush by its force as just a distraction from the primary purpose of this discourse which in his or her eyes is a thoroughgoing rebuke of the legalistic and hypocritical religious leaders of first-century Judaism. This dismissal, though, is a mistake. For reasons discussed below, Jesus meant his entire instruction for the good of the people in His audience as well as the continuing people of God. For in fact, what Jesus desired is that His people grow in obedience and faithfulness in all circumstances. God has ordained bad leadership as well as good and is working out his purposes for the good of those who love him in all leadership situations. Thus the believer is called to a faithful and obedient response even when under bad leadership in God's sovereignty and Matthew 23:1-3 is evidence of this.

* JONATHAN D. STUCKERT (EdD 2016, The Southern Baptist Theological Seminary) is Registrar at Reformed Theological Seminary, Atlanta. Email: jstuckert@rts.edu. 
Below I consider a selection of interpretations of these three verses taken from various periods of the history of the Church with particular attention paid to the interpretation of the first half of verse 3 . Included in this survey will be pre-critical interpretations in order to mitigate historical myopia and to value the illumination of the Holy Spirit in the breadth of the history of the Church. This evaluation contends that it is entirely reasonable and also preferable to read this passage as a genuine instruction to the people of God even verse 3a. This leads immediately into a review of select passages in the Old and New Testaments. These passages provide support and expansion of God's will for His people in their relationships to authority in general and religious authority in particular. Having accomplished this canonical review, then a description of this passage is given that emphasizes how it is a word for the Church today. This description then leads naturally into a concluding offer of a practical implication for the reader in his or her life. These interpretive goals answer Dale Bruner's (2004: 429) almost exasperated plea for the relevance of the entire chapter. He writes, '... would Matthew put this chapter in his «teaching> Gospel only for invective and not for instruction? And does Matthew anywhere show a reluctance to critique Christian disciples? I think that Matthew intends this chapter as a massive end-of-the-Gospel warning to the people of God, old and new'.

\section{Justification for an Imperatival Reading of the Text}

First, in my reading and studying of the text I do not judge that Jesus is using irony, even though this may be the easier reading (Talbert 2010: 256), but rather Jesus is giving real instruction to people who found themselves under bad leadership and needed to be guided in a faithful and obedient response. This interpretation is in contradiction to D. A. Carson (1984: 473474 ) and R. T. France (2007: 860). Second, I contend that this reading is in keeping with the overall character of God's concern for his people who are in their time under less than ideal leadership.

A verse by verse consideration given below focuses on a key question for each verse as to whether this passage should be taken as a literal command or something else entirely. For verse 1 the context of the audience will be considered. For verse 2 the background and meaning of the seat of Moses will be considered. And, finally, for verse 3 a series of compelling reasons for taking 3a as a literal command of Jesus will be offered while also referencing again evidence from verses 1 and 2 .

\section{The Audience}

Many interpreters fall into the trap of idealizing the audience. The audience members are not the perfected ones; instead, they are in need of learning obedience too, even obedience of the heart shown in actions. Leon 
Morris (1992: 571) writes this in reference to this discourse before the audience shifts in verse 13, 'he has some strong denunciations of the Pharisees, but he is not so much criticizing them as drawing his hearers' attention to the kinds of lives they should be living'. For this reason, then, an imperatival reading makes sense. Taken as a command the clause then reminds them that they need the Word of God and at this point in time that primarily would come through the God-ordained leadership of the time who had the access and knowledge to be able to speak the words of Scripture to them. As David Garland (1979: 38-39) points out, the crowds are not members of the New Testament Church, yet, and were under the leadership and authority of the scribes and Pharisees. Until such time as they would be under other leadership, this was God's means for them to hear His Word and be pointed to its fulfillment in His Son. This is a function of the scribes and Pharisees that they fulfilled even unknowingly as the author of the Opus imperfectum in Matthaeum (2010: 2.344) reminded his readers at the dawn of the fifth century.

Craig Blomberg (1992: 340) provides an argument close to my own (although he assigns more of a warning tone whereas I would tend toward viewing Jesus's imperative in $3 \mathrm{a}$ as a pastoral concern for their nurture in the Scriptures, but these are differences of degree). He also notes the specific designation of the audience as an evidence of the purpose for verses 2 and 3, 'Matthew describes Jesus' audience here as the «crowds〉 and «disciples». Thus the harsh words against the scribes and Pharisees are probably not so much directly addressed to them as to others-to warn those who still had a chance to repent against following their damning example'.

To summarize, the direction of Jesus's discourse in this passage argues against a rhetorical flourish such as irony; rather he is here giving direct and needed instruction to his followers, both committed and uncertain.

\section{The Seat of Moses}

The seat of Moses may be the element most shrouded in mystery. Mark Powell (1995: 430) notes, 'Any interpretation of this text, then, must begin with the recognition that we are expected to know something that we do not know'. There have been many theories given, and they may include archaeological evidence (Newport, 1990; Newport, 1995: 80-85) or literary evidence of a later period, but in the end, all the theories are admittedly speculative. There is just not enough evidence to be very dogmatic on an identification of the seat. However, most if not all the theories do support the contention that there was an element of authority in this reference made by Jesus. And that is what we will most consider briefly here.

From a textual standpoint, the evidence prefers a figurative interpretation of the chair slightly. Davies and Allison (1988: 268) suggest that the dif- 
ference in number between the plural scribes and Pharisees and the one chair may point to non-literal interpretation. However, for the interpretation of this passage, deciding between the literal or figurative may not be necessary. David Turner (2008: 548) finds many of the theories ultimately unimportant for the intended message. He writes:

The chair or seat of Moses may be a metaphor or may refer to such a seat in synagogues where authoritative teaching occurred, although the evidence for an actual seat comes from later times. In any event, occupying this 'chair' signified the ongoing exercise of the quasi-Mosaic authority that came from Sinai.

But, how could Jesus make the claim that his opponents had any authority, much less stand in the tradition of Moses? Leon Morris (1992: 572) sees the scribes and Pharisees as continuing in the tradition of Moses even while they at times went beyond the law in their strict instruction and practice. He writes:

The scribes and the Pharisees were not evolving new schools of interpretation but trying hard to make clear what Moses had said, and, where there were problems, in helping people understand what actions were called for on their part as they tried to put into practice things that Moses commanded.

Interpreters associated with the Reformation and its development and growth found in this interpretation of the seat of Moses a way to make sense of the pre-Reformation church. John Calvin (1949: 75) answering the question 'Should we obey teachers without exception?' draws helpful distinctions to consider.

He does not absolutely compare any kind of doctrine with the life, but the design of Christ was, to distinguish the holy Law of God from their profane works. For to sit in the chair of Moses is nothing else than to teach, according to the Law of God, how we ought to live... That man, therefore, sits in the chair of Moses, who teaches, not from himself, or at his own suggestion, but according to the authority and word of God. But it denotes, at the same time, a lawful calling; for Christ commands that the scribes should be heard, because they were the public teachers of the Church.

Protestant scholastic Francis Turretin wrote his Institutes of Elenctic Theology a little over a hundred years after the death of John Calvin. His book of questions sought to address a number of theological controversies. Among those questions were the role of Scripture and tradition in matters of controversy and the nature of the Church especially prior to the Protestant Reformation. In his polemics on these issues of controversy he employed this pas- 
sage from Matthew 23. There is this paragraph from his answer on the authority of Scripture as an example (1992: 1.60).

The 'seat of Moses' (Matthew 23:2) is not the succession in the place and office of Moses or the external court of a supreme judge to whom the authority in question belongs (for the seat of Moses was not in existence nor was any such privilege attached to it); rather it is the promulgation of the true doctrine delivered by Moses (as the ordinary gloss on Deuteronomy 17 has it, 'the seat of Moses is wherever his doctrine is'), and the chair of Peter is wherever his doctrine is heard. So those who have been teachers of the law delivered by Moses are considered to have taught in Moses' seat, as Hilary observes (Commentarius in Matthaeum 24.1 [PL 9.1048]). Therefore the Pharisees teaching in Moses' seat were to be heard as far as they faithfully proposed to the people his doctrine, without any admixture of their own.

This view of Matthew 23 was consistent with Turretin to the point of recognizing the authority of teachers in the Roman Church. He, though, describes how that authority became transitional with the rise of the Protestant churches (1992: 3.65).

Thus in the Christian church the teachers of the Roman church could be considered true teachers and were to be heard as far as they set forth the word of God and the doctrine of salvation; but when to this truth they tacked on their falsehoods, to this word of God their traditions, to this spiritual bread their own leaven, then they were sitting in their own seat and were no longer to be heard (as they were not heard by believers, who as rational sheep knew and followed the voice of Christ, but separated the leaven from the healthful food, so that the former being left, they could feed upon the latter.

Martin Luther earlier also grappled-with himself and others, including the 'Leipzig Goat'-over the authority of the Roman priests and prelates and the divergence with their actions and character (1982: 3.297). This difficult saying of Jesus became a way for them to understand the difficult historical moment the inhabited.

Considering the data we have, or lack thereof, it does seem to be reasonable to see in verse 2 a genuine recognition of the authority of the teaching of the scribes and Pharisees when it is in concert with the revelation of God in the Old Testament.

\section{The Words of the Scribes and the Pharisees}

The first consideration necessary for verse 3 is whether or not $3 \mathrm{a}$ is a true command or if it is something else entirely. More than one scholar has suggested that $3 \mathrm{a}$ is an ironic rhetorical flourish meant to galvanize the audience against the competitors of Jesus. Suggesting an even stronger rhetori- 
cal jab to the scribes and Pharisees through its directness, Davies and Allison (1988: 270) offer this opinion.

The key to an alternative interpretation is to see па s as rhetorical hyperbole (cf. 3.5). The sentence indicts the scribes and Pharisees by parading their inconsistencies. 'Do what they preach' is less practical imperative-although it does presuppose continued contact with Jewish teachers - than proof of a bad character which cannot be excused by ignorance... The focus is not upon Christian obedience, but upon the opponents' knowledge which condemns them.

This viewpoint stands in contradiction to my own, and it would seem to me that the facts of the very specific audience designations and transitions (from the 3rd person to the 2nd person plural in verse 13) argue against the position of Davies and Allison. Let's consider that theory broadly first. The case for irony is based almost exclusively on this argument: verse $3 \mathrm{a}$ does not demonstrate consistency with how Jesus interacted with and spoke to the Jewish religious leaders most specifically in the Gospel of Matthew (cf. Matthew 15:1-9, and 16:1-12). This argument is a fairly strong point and made from the text of Scripture (i.e. it is not speculative), so we must take it seriously. There are, however, some equally vigorous criticisms made against the ironic view.

1. We cannot agree that Jesus never said anything that on its face was contradictory to something else he says in the biblical record. For example, consider Matthew 12:30, Mark 9:40, Luke 9:50 and 11:23. Jesus did not always speak in explicitly consistent ways, but he always spoke truth.

2. Noel Rabbinowitz (2003: 433) makes the case that those that see this statement as irony have confused exaggeration with irony. Irony implies that the opposite is true and therefore is out of keeping with the previous statement concerning the Mosaic authority of the scribes and Pharisees. Exaggeration, however, implies that what Jesus is saying is necessarily correct, but perhaps does not extend to absolutely everything that comes out of the mouth of the scribes and Pharisees. This view seems in better keeping with the immediate context of the seat of Moses.

3. Why would Matthew not have thought to have provided any literary cues (since his readers will be missing the physical and oral cues that are typically present when a speaker uses irony) to tip his audience off to the fact that irony was taking place? Ulrich Luz (1989: 101-102, n. 48) makes the point that if this is irony, then it would be tough for readers to understand an ironical statement at the beginning of discourse.

4. The particle ổ $\nu$ seems to lead into a natural connection with the position they had in the tradition of Moses while limiting it to only what they said that was in that tradition, not the traditions that had since been developed (Morris, 1992: 572-573). Robert Gundry (1982: 454) states that 'oủ $\nu$ is a favorite of his [Matthew's] $(35,11)$ and makes the sitting of the scribes and Pharisees on 
Moses' seat the basis for the command in verse 3'. He goes on to write concerning 3a, 'Since this command deals with what the scribes and Pharisees say when they sit in Moses' seat-i.e., when they rehearse the OT law-we need not suppose that the first half of the command needs to be understood as sarcastic, or that the first half is merely a foil to the second half, where the real meaning lies, or that Matthew has taken from the Jewish Christian tradition a legalistic saying disagreeable with his following statements and with 16:11-12, or that he is making a tactical attempt to avoid a complete break between the church and synagogue'.

Blomberg (1992: 340-341) also provides an argument similar to that of this paper, but in his case with a little less force.

Jesus begins by acknowledging that these leaders are duly authorized officials within Judaism (verse 2). 'Moses' seat' referred to an actual chair in the synagogues and stood for the teaching authority of Moses' successors as interpreters of Torah (cf. Deuteronomy 17:10). The expression is roughly parallel to our reference to the pulpit as the symbol for preaching or scriptural exposition. Verse 3a, however, seems completely out of keeping with the rest of the passage and therefore has understandably been taken as irony, not to be literally obeyed... Or perhaps Jesus is implying that people must obey their religious teachers to the extent that their teaching coheres with that of Moses, but no further. This interpretation fits the more positive, recent understanding of the Pharisee's goals in creating a 'fence around the Torah'-guidelines to make it easier to obey Moses' law.

He recognizes that Jesus's reference to the seat of Moses has an authoritative aspect to it, but then writes sympathetically of the ironic position before offering a more literal and imperatival reading suggestively. This reading is not contradictory in that France (2007: 859) says that on the face of it the expression of Jesus about the seat of Moses does recognize a legitimate authority for the scribes and Pharisees. France juxtaposes this against what follows in the passage to use this as an argument that $3 \mathrm{a}$ must, however, be ironic. As can be seen from the above, while many interpreters tag $3 \mathrm{a}$ as irony and quickly move on to the remainder of the discourse, it is not such a problem-free identification of this clause.

Other competing explanations for $3 \mathrm{a}$ are present in a historical-critical analysis of the text, most notably in source and redaction criticism. Benedict Viviano (1990: 4, 8, and 12) laments that much of the most recent historical criticism, specifically referencing redaction criticism, does not have much history to it at all. Instead, he contends that it has become pure literary criticism (4). However, he offers a more historical criticism that in many ways affirms the imperatival force of the text (8), but with a qualification that it only pertains to the pre-paschal period before authority is given by Jesus through the Spirit to the early Christian leaders (12). The work done in this 
area is intricate and complex and supposes quite a bit of knowledge necessary for not only modern readers to discern the meaning of the text, but also the original audience of Jesus and the original recipients of the Gospel of Matthew. Critical scholars are very much interested in the motivation and purposes of Matthew as he arranged-or in some opinions created-this discourse and his purposes for including 3a. These speculations primarily center on the church's relationship to the synagogue and the Jewish leadership at the time of the Gospel's composition (see France, 2007: 854-855 and Luz, 1989: 100-101). These explanations, though, draw pointed criticism from scholars such as Carson (1984: 470).

Attempts to define the situation in Matthew's church on the basis of this chapter are precarious... Objections to the contrary, there is no real anachronism to warrant such discussion, which is scarcely more than fanciful though learned speculation. Obviously Matthew is telling us what Jesus says, not what the church says. Even if we assume that Matthew's choice of what he includes largely reflects the situation at the time he wrote, it is naïve to think twentieth-century scholars can reconstruct the situation in detail.

In case it should be thought that $3 \mathrm{~b}$ is forgotten, very briefly it is uniformly understood to be a valid command, and an important one at that. This designation provides evidence for seeing $3 \mathrm{a}$ as the same. For instance, Luz (1989: 101-102, n. 48) points out that if verse $3 \mathrm{a}$ is meant that one actually should not do what the scribes and Pharisees teach, the rhetorical opposition to verse $3 \mathrm{~b}$, which for Matthew is important, would be undermined'. It should be noted, though, that Luz is equivocal in his support for a robust command in $3 \mathrm{a}$, he sees it as more of a concession. The emphasis in the text, for Luz, is $3 \mathrm{~b}$, not $3 \mathrm{a}$. Further, it is $3 \mathrm{~b}$ that leads into the criticisms of the scribes and Pharisees that will provide the negative example not to be followed by the burgeoning Christian community.

\section{Value in a Canonical Approach}

There are a number of ways that scholars have approached this text. Most have sought to uncover the history of its context and the history of its composition. Others have relied upon a close examination of the linguistic features of the text as we have it. Many combine all of these elements. In addition, some direct attention to Old Testament foundations and New Testament comparisons. However, little is devoted to the manner in which this text either follows or cuts against the grain of the Bible's teaching for those that find themselves under less than ideal leadership. Also, mostly missing is any word for the church based on verses 2-3a. For these reasons, a canonical approach may be an important avenue for understanding the meaning of this difficult text. For this study, the canonical agenda will mirror two of 
the concerns set forth by Rolf Rentdorff (1994: 144-145). These include (1) attempting to understand the given text in its completeness even if it contains certain tensions or inconsistencies or even contradictions, and (2) trying to understand the text in its given form even if it is difficult to do so. Also, of concern is a 'whole Bible approach' that gives preference to being church centered. For a brief discussion, (although not a wholly positive appraisal) of this see Daniel Trier (2008: 115).

\section{How Does This Text Fit within Scripture?}

In this non-comprehensive, but still key, section we will consider Old Testament background that may underlie this text along with the continuing revelation the lies beside it. Early interpreters in the Church commonly took advantage of this hermeneutic. Jerome's (2002: 1b.163) observations in his work on the Gospel of Matthew demonstrate this inclination of the early church.

... on account of the dignity of the priest and their reputation, he encourages the people to obey them, considering not their works but their teaching. What he says is this: 'The scribes and Pharisees sit upon the throne of Moses', showing this as a throne of teaching about the law. And we ought to accept this because of what is said in the psalms: 'He does not sit in the seat of scoffers' and 'He overturned the seats of those who sold pigeons'.

\section{Old Testament}

There is one fairly clear echo in the Old Testament found in Deuteronomy 17 where Moses gives the people instructions for obeying priests and judges. This injunction of Moses to follow the leadership and what they say is completely within the realm of the possible as a foundation for the instruction of Jesus in 3a. Noel Rabbinowitz (2003: 432-433) makes a forceful statement in this connection:

His command to do what the Pharisees teach invokes Deuteronomy 17:11, the very text upon which the authority of the Sanhedrin, the Sages, and later rabbis is based... Jesus' command to do and keep whatever the Pharisees say clearly resembles this passage and it is unlikely that his choice of words was merely coincidental. If Jesus did not intend for his listeners to take his command seriously, it is unlikely that he would have used language invested with such legal and binding authority. To have done so would have certainly confused Jesus' listeners.

Craig Blomberg (2007: 84) suggests a slightly fainter echo in Malachi 2:7-8. His suggestion is an especially interesting comparison since he identifies these verses in the context of a warning to the priests. Commenting on verse 7, E. Ray Clendenen (2004: 314) marvels at the role of the one who transmits God's Word, 'Those who proclaim God's written Word are no less 
important to his redemptive program than those who previously served as 'prophets', since both carry God's message (cf. 2 Peter 1:19-21)'. Many commentators have overlooked this important connection to Malachi. This neglect is unfortunate since it so closely parallels Matthew 23. These two passages serve to show a pattern of God calling His people to obey those that had been placed in a position to speak his Word to the people.

\section{New Testament}

Few seem to offer much indication to how this command finds support in the New Testament canon. Instead, most attention on the New Testament has been paid either to demonstrate the incongruity of a straightforward reading of Matthew 23:3a or to determine the source and redaction history of the passage.

Staying within the Gospel of Matthew, Rabbinowitz (2003: 434) makes the case that the parable of the wicked tenants in Matthew 21 supports the idea of the scribes and Pharisees still possessing the authority to teach the law at the time of the discourse and for the immediate future. This passage is a reminder of the unfolding nature of God's redemptive plan. There have been and will be times when God's people are to exercise patience and faithfulness in the midst of trials, including bad leadership, waiting on God to move and bring about reformation and cleansing. We also have the words of Jesus in Mark 9:38-40 and Luke 9:49-50 when he speaks about those casting out demons in his name, but who are not part of his disciples. Jesus shows here that the key is that the Word of God, in this case, testimony to Jesus himself, is going out.

Now, looking at Paul, he gives a surprising analysis of his competitors and his corpus in Philippians 1:12-18. Even though they have arrayed themselves against Paul, they are preaching Christ, and for this Paul gives approval and thanks. Scripture demonstrates that God uses very broken people to deliver his Word to his people in all generations, e.g. Moses, David, and Saul. At the same time, God calls his people to pay attention to the word while not being led astray. So, how does this apply to church today?

\section{What Is God's Word for the Church?}

Just like the audience specified for this passage of Scripture, the words of Jesus continue to find an audience that is in need of His direction. Leon Morris (1992: 573) points to the importance of the transmission of God's word writing, "When the Pharisees brought out the significance of the teaching of Moses, they were doing something of great importance for the people of God. What they were teaching was both meaningful and creditable: they should be heard'. 
So, the word for the church is the Word. God in all times and all situations wants the church to be concerned first and foremost with God's Word of revelation. There is certainly a place for analyzing and refining leadership style and for training leaders of programs and small groups and of all the ways in which the church does its work, but the church needs to remember its first call is obedience to the Word.

Consequently, how does that play out for the follower? And it should be noted that follower describes just about everybody. Even most leaders are still following someone.

Sitting under poor leadership can drain the spiritual life from a follower of Jesus. But, must it? And, further, can it be an opportunity for spiritual growth? The key implication of this passage and the canonical trajectory of God's instructions for His people is this: be cautious about presuming the will of God. What does that mean?

It means that in our flesh we often make the following presumption. God would not want for me to sit under leadership that does not practice what it teaches. It may not be too much of stretch to say that many of us even think that God does not want us to be under any leadership that is not the best, which is not excellent in every respect. We have to guard against this presumption on God's will. These are cultural accretions on our souls.

God ordained that the early followers of Jesus along with the rest of Jews were to be under the leadership of scribes and Pharisees as they taught and interpreted the Word of God for the people. God knows that his people perish without his word. And he does not want them to die, but rather to be fruitful and grow; however, this may often come through difficult times.

The seventh chapter of Matthew is a fitting passage to consider in summing up the will of Jesus for his people. In verses 15-23, Jesus excoriated the false prophets, even those who do speak in his name, because they were still lawless and their end is destruction.

Immediately following, though, in verses 24-27 he used an extended simile to drive the point home to his audience that a person must both hear his word and act upon it. Pointing the people to this truth in their relationship to God caused them, and should cause us, to be amazed 'for he was teaching them as one having authority, and not as their scribes'.

The authority of the scribes and Pharisees was derivative and depended on their delivery of God's Word, but Jesus has the authority in himself. So today we too must measure the message even before measuring the man or woman. God may move us out from under hypocritical leadership, but he may delay because he is working in us through his Word and the Spirit and is not anxious as we are. 


\section{Bibliography}

Blomberg CL (2007) Matthew. In Beale GK and Carson DA (eds) Commentary on the New Testament Use of the Old Testament. Grand Rapids, MI: Baker Academic.

Blomberg CL (1992) Matthew. Nashville, TN: Broadman Press.

Bruner FD (2004) Matthew: A Commentary, The Churchbook Matthew 13-28. volume 2. Grand Rapids, MI: Eerdmans.

Calvin J (1949) Commentary on a Harmony of the Evangelists, Matthew, Mark, and Luke. In Pringle W (trans) Commentary on a Harmony of the Evangelists, volume 3. Grand Rapids, MI: Eerdmans.

Carson DA (1984) Matthew. Grand Rapids, MI: Zondervan.

Davies WD and Allison DC (1988) A Critical and Exegetical Commentary on the Gospel According to Saint Matthew, volume 3. Commentary of Matthew 1928. Edinburgh: T. \& T. Clark.

France RT (2007) The Gospel of Matthew. Grand Rapids, MI: Eerdmans.

Garland DE (1979) The Intention of Matthew 23, volume 52. Supplements to Novum Testamentum. Leiden: E. J. Brill.

Gundry RH (1982) Matthew: A Commentary on His Literary and Theological Art. Grand Rapids, MI: Eerdmans.

Jerome (2002) Commentary on Matthew. In Simonetti M (ed) Matthew 1428, volume 1b. Ancient Christian Commentary on Scripture. Downers Grove, IL: InterVarsity Press.

Luz U (1989) Matthew 21-28: A Commentary. Linss WC and Crouch JE (trans) Koester H (ed). Minneapolis, MN: Augsburg.

Morris L (1992) The Gospel According to Matthew. Grand Rapids, MI: Eerdmans.

Newport KGC (1990) A Note on the 'Seat of Moses'. Andrews University Seminary Studies 28(1): 53-58.

Newport KGC (1995) The Sources and Sitz im Leben of Matthew 23. Journal for the Study of the New Testament Supplement Series 117. Sheffield Academic Press.

Opus Imperfectum in Matthaeum (2010). In Kellerman JA (trans) Oden TC (ed) Incomplete Commentary on Matthew, volume 2. Downers Grove, IL: IVP Academic.

Powell MA (1995) Do and Keep What Moses Says (Matthew 23:2-7). Journal of Biblical Literature 114(3): 419-435.

Rabbinowitz NS (2003) Matthew 23:2-4: Does Jesus Recognize the Authority of the Pharisees and Does He Endorse Their Halakhah? Journal of the Evangelical Theological Society 46(3): 423-447.

Rendtorff R (1994) Canonical Interpretation: A New Approach to Biblical Texts. Studia Theologica 48(1): 3-14.

Talbert CH (2010) Matthew. Grand Rapids, MI: Baker Academic. 
Taylor RA and Clendenen ER (2004) Haggai, Malachi. volume 21a: The New American Commentary. Nashville, TN: Broadman Press.

Trier DJ (2008) Theological Interpretation of Scripture. Grand Rapids, MI: Baker Academic.

Turner DL (2008) Matthew. Grand Rapids, MI: Baker Academic.

Turretin F (1992) Institutes of Elenctic Theology. In Giger GM (trans) Dennison JT (ed) Institutes of Elenctic Theology, volume 1. Phillipsburg, NJ: P \& R Publishing.

Turretin F (1992) Institutes of Elenctic Theology. In Giger GM (trans) Dennison JT (ed) Institutes of Elenctic Theology, volume 3. Phillipsburg, NJ: P \& R Publishing.

Viviano B (1990) Social World and Community Leadership: The Case of Matthew 23:1-12,34. Journal for the Study of the New Testament 39(*): 3-21. 